\title{
Crude glycerin as an energy feed for dairy cows
}

\author{
Glicerina bruta como alimento energético para vacas de leite
}

\author{
Ozana de Fátima Zacaroni \& Cristielle Nunes Souto*
}

Universidade Federal de Goiás, Goiânia, GO, Brasil. *Autor para correspondência: cristielle_nunes@hotmail.com

Submission: 03/08/2017 / Acceptance: 01/03/2019

\begin{abstract}
Crude glycerine is a residue generated from the production of biodiesel. As there was an increase in the demand for biodiesel observed in recent years, there was also a concomitant increase in the production of glycerin, and this by-product is not being used by industries. Thus, new alternatives can be viable, such as the use in dairy cows' food. The use of glycerin in the animal diet has shown to be a viable alternative to nutritional and economic aspects. Our aim in this review was to demonstrate the use of glycerin in dairy cow diets and the possible effects on its milk production. In several studies it is possible to observe that the crude glycerin can be included in the diet of ruminant animals without causing negative effects on their metabolism, ruminal fermentation and milk production. Studies on the deleterious effects of the inclusion of crude glycerin with high methanol content in the dairy cow diet should be performed.
\end{abstract}

KEYWORDS: glycerol, methanol, sensorial feed additives.

\section{RESUMO}

A glicerina bruta é um resíduo oriundo da produção de biodiesel. Com o aumento da demanda por biodiesel nos últimos anos, houve também um aumento na produção de glicerina, um co-produto que não é utilizado pelas indústrias. Assim, novas alternativas podem ser viáveis, como o uso na alimentação de vacas leiteiras. $O$ uso da glicerina na dieta dos animais demonstra ser uma alternativa viável no que diz respeito aos aspectos nutricionais e econômicos. Nosso objetivo nesta revisão foi abordar a utilização da glicerina em dietas de vacas leiteiras e seus possíveis efeitos sobre a produção de leite. Em vários estudos, é possível observar que a glicerina bruta pode ser incluída na dieta de ruminantes sem causar efeitos negativos sobre o metabolismo, fermentação ruminal e produção de leite. Estudos sobre os efeitos deletérios da inclusão de glicerina em bruto com alto teor de metanol na dieta de vacas leiteiras devem ser realizados.

PALAVRAS-CHAVE: glicerol, metanol, aditivos sensoriais na alimentação animal.

\section{INTRODUCTION}

Biodiesel is a renewable fuel, mainly produced by esterified vegetable oil or animal fat with methanol, having alkali as a catalyzer ( $\mathrm{HU}$ et al. 2012). Brazil produced 2.5 billion liters of biodiesel in 2013. It is estimated that each liter of biodiesel generates approximately $100 \mathrm{~mL}$ of the by-product crude glycerin (DASARI et al. 2005), containing variable glycerol content (WILBERT et al. 2013). Glycerol has energy content similar to corn starch and can be used as animal food (DONKIN et al. 2009, WILBERT et al. 2013). However, crude glycerin contains impurities, such as methanol, sodium hydroxide, fat, esters, and low amounts of sulfur, protein, and minerals (CELIK et al. 2008).

Crude glycerin may contain up to $14 \%$ of methanol (HANSEN et al. 2009), which has been shown to be potentially toxic to animals (CHALMERS 1986). Refining crude glycerol to pure glycerin ( $>98 \%$ glycerol content) would make it a more desirable feed source, however it may not be economically feasible (HU et al. 2012). Glycerol, the main component of crude glycerin, has high energy content, which is approximately the same as that of corn starch and can be used for animal feeding (DONKIN et al. 2009, WILBERT et al. 2013).

One of the major challenges for the use of crude glycerin is the inconsistency of its composition since it varies with the feedstocks, production processes, and post-treatments involved in the biodiesel production. Upgrading or refining crude glycerol to technical grade glycerin ( $>98 \%$ glycerol content) makes its composition more consistent, but currently this is not economically viable (HU et al. 2012). One concern is 
about the methanol content in crude glycerin, in a range of $<0.01$ to $13.94 \%$ (HANSEN et al. 2009). Methanol is metabolized to formaldehyde by the liver enzyme alcohol dehydrogenase (ADH) (BARCELOUX et al. 2002, KRAUT \& KURTZ 2008).

Formaldehyde is then metabolized via enzyme formaldehyde dehydrogenase to formic acid format then being metabolized to $\mathrm{CO} 2$ and $\mathrm{H} 2 \mathrm{O}$, a process that depends on liver tetrahydrofolate concentrations (BARCELOUX et al. 2002, KERNS et al. 2002). This pathway is easily saturable, contributing to the accumulation of formic acid in the blood (KRAUT \& KURTZ 2008). Formic acid can cause metabolic acidosis, hyperosmolality, retinal damage with blindness, putaminal damage with neurologic dysfunction (KRAUT \& KURTZ 2008). Our objective in this review was to address issues about the dairy cow performance, digestion, metabolism and blood acid-base balance in response to the inclusion of crude glycerin.

\section{LITERATURE REVIEW}

\section{Glycerol}

Glycerol is a carbohydrate molecule (C3H8O3), odorless, hydroscopic, sweet-tasting liquid that has the potential to replace corn in the diet. SCHRÖDER \& SÜDEKUM (1999) estimated that glycerol has net energy value of $1.98-2.29 \mathrm{Mcal} / \mathrm{kg}$, which is approximately equal to the energy contained in corn starch. The corn grain net energy content is approximately $2.0 \mathrm{Mcal} / \mathrm{kg}$ (NRC 2001). According to the FDA (2006), glycerol is recognized as a safe ingredient to use as animal feed.

Glycerol is present in crude glycerin from biodiesel production or can be purchased as pure glycerol, with more than 99\% purity. According to LINKE et al. (2004), in order to be glucogenic, glycerol must be delivered in water to associate with the liquid fraction of the rumen contents or be able to bypass rumen in a way to be absorbed as glycerol. In the rumen, glycerol may be converted to propionic and butyric acids. Glycerol converted to butyrate will be metabolized to $\beta$-hydroxybutyrate (BHBA) by the rumen epithelium. Therefore, glycerol metabolized to butyrate is ketogenic, rather than glucogenic. Glycerol that bypasses ruminal fermentation may be a highly efficient glucogenic substrate, because it can enter the gluconeogenesis pathway in the liver at the triose phosphate level and is not dependent on the rate limiting enzymes pyruvate carboxylase and phosphenolpyruvate carboxykinase for its conversion to glucose by glycerol kinase (LENG 1970). Glycerol kinase converts glycerol ( $\mathrm{Km}=3$ to $10 \mu \mathrm{M})$ (LIN 1977) and ATP to glycerol-3-phosphate and ADP, an intermediate step where glycerol is directed to glycolysis or gluconeogenesis.

Dairy cows in negative energy balance have pathways activated for the use of glycerol released by the mobilization and hydrolysis of triglycerides from body fat. This activity depends on the absorption of glycerol rather than the fermentation of glycerol to propionate and butyrate (HIPPEN et al. 2008). The single most important nutrient required for milk synthesis is glucose, although nearly all glucose consumed by the dairy cow is degraded in the rumen to volatile fatty acids (VFA), which are absorbed and metabolized by the liver (HIPPEN et al. 2008).

During lactation, over $70 \%$ of the synthesized glucose is used for milk production (ELLIOT 1976). The liver is responsible for converting propionate from starch fermentation in the rumen, glucogenic amino acids, and glycerol from adipose triglycerides into glucose (HIPPEN et al. 2008). HARZIA et al. (2013) evaluated the replacement of starch with crude glycerin. Eight primiparous mid-lactation dairy cows were used in a replicated $4 \times 4$ Latin Square experiment with 21-d periods, having one square of rumen cannulated cows. Four iso-energetic diets were evaluated. Control cows were fed barley based TMR (T0), and other treatments were formulated by replacing $1 \mathrm{~kg}(\mathrm{~T} 1), 2 \mathrm{~kg}$ (T2), and $3 \mathrm{~kg}$ (T3) of barley with crude glycerin. The crude glycerin had $82.6 \%$ glycerol, $9.3 \%$ salts, $7.1 \%$ water, 0.6 ether extract, and $0.4 \%$ methanol. Treatments T2 and T3 increased the molar proportion of propionate and butyrate in rumen VFA. Treatment T3 increased rumen valerate proportion. Glycerol increased milk protein and lactose contents. Milk coagulation was increased as barley was replaced with glycerin.

DONKIN et al. (2009) evaluated the effect of feeding glycerol as a replacement to corn grain on intake, milk yield, milk composition, and total-tract nutrient digestibility in lactating cows. Sixty Holsteins were blocked based on parity and milk yield and randomly assigned 56 days for diets containing $0,5,10$ or $15 \%$ pure glycerol. Daily milk yield was around $37 \mathrm{~kg}$ and was not affected by the treatment. In the last week of the experiment, a modest decrease in dry matter intake (DMI) of cows fed $15 \%$ glycerol was observed. Milk urea- $\mathrm{N}$ content was reduced by glycerol feeding. Milk solids content did not differ. Total tract neutral detergent fiber (NDF) digestibility was lower for cows fed $5 \%$ glycerol. There was a linear increase in blood glucose content in response to glycerol feeding. Replacing corn with up to $15 \%$ glycerol in the diet had no 
adverse effect on milk yield or composition.

BOYD et al. (2011) evaluated the effect of direct-fed microbial and glycerol supplementation (2x2 factorial) with milk yield, feeding efficiency, and nutrient digestibility during the hot weather. Sixty midlactation Holsteins were fed for 10 weeks after a 2-week standardization period: Cows received $400 \mathrm{~g} / \mathrm{d}$ of glycerol. There was no detectable interaction between factors, except for the total tract nutrient digestibility. Apparent digestion of forage dry matter (DM), crude protein (CP), Acid Detergent Fibre (ADF) in the rumen was increased in cows supplemented with glycerol. There was no glycerol effect on DMI, milk yield, body temperature, or blood glucose content. CARVALHO et al. (2011) replaced corn with pure glycerol in diets for transition dairy cows. Twenty-six multiparous Holsteins were paired blocked based on expected calving date and randomly assigned to a diet containing high moisture corn or glycerol plus soybean meal. Treatments were fed from 28 days before the expected calving date to $56 \mathrm{~d}$ postpartum. Glycerol was included at 11.5 and $10.8 \%$ of diet DM during the pre-partum and post-partum periods, respectively. There was no treatment effect on pre- and post-partum DMl, milk yield, milk composition, milk urea- $\mathrm{N}$, and energy balance. Prepartum blood glucose content was decreased in cows fed with glycerol, and this same trend was observed post-partum. Blood $\beta$-hydroxybutyrate (BHBA) concentration was increased by glycerol feeding. Glycerol increased the ruminal concentrations of propionate, butyrate, and valerate, and decreased acetate, isobutyrate, and the acetate to propionate ratio.

\section{Crude glycerin}

Crude glycerin is a major byproduct from the biodiesel production process. It is estimated that approximately $1 \mathrm{~kg}$ of crude glycerin is generated for every $10 \mathrm{~kg}$ of biodiesel produced (HU et al. 2012). With the rapid growth of the world's biodiesel production in recent years, a large surplus of glycerin has been created (JONHSON \& TACONI 2007). The production of biodiesel in the world in 2013 was 25 billion liters, Brazil produced around 11\% (BIOFUEL DIGEST 2013). It was projected that the world biodiesel market would reach 140 billion liters by 2016, which implied 15 billion liters of crude glycerin (ANAND \& SAXENA 2011).

According to the "Agência Nacional de Vigilância Sanitária" (ANVISA 1999) (Resolution 386/1999), glycerin use is an allowed humectant for human and animal consumption. However, glycerin quality standards were not defined when used as animal feed, nor the obligation of prior registration for glycerin (ANVISA 1999). In May 2010, the "Ministério da Agricultura, Pecuária e Abastecimento" (MAPA) regulated the use of glycerin (crude and blonde) as a feed ingredient for animals and defined quality standards, such as the contents of glycerol (minimum $800 \mathrm{~g} / \mathrm{kg}$ ), moisture (maximum $130 \mathrm{~g} / \mathrm{kg}$ ), methanol (maximum 159 $\mathrm{mg} / \mathrm{kg}$ ), sodium, and minerals. The glycerol content of glycerin (Purity) is variable and reflects the different stages of biodiesel production. Low purity glycerin has high content of water and methanol. High purity glycerin (>99\% of glycerol) is the most valuable product, however the identification of alternative uses for low purity glycerin may make biodiesel production more competitive in the growing global biofuel market (OMAZIC et al. 2013).

Crude glycerin has little economic value due to the presence of various impurities such as methanol, soap, fatty acid methyl esters, and alkaline catalyst residues (HU et al. 2012, MCCOY 2006, SANTIBANEZ et al. 2011). Crude glycerin availability has become a serious issue for the biodiesel industry (JOHNSON \& TACONI 2007). Considerable research has been conducted on potential uses of crude glycerin. Impurities present in crude glycerin significantly affect its proprieties and its conversion to value-added products (HU et al. 2012). Soap and methanol can have negative impacts on algae production of docosahexaenoic acid from crude glycerin (PYLE et al. 2008). The high salinity (sodium or potassium) from crude glycerin can inhibit microbial activity when crude glycerin is anaerobically digested (SANTIBANEZ et al. 2011).

$\mathrm{HU}$ et al. (2012) described the physical and chemical properties of five crude glycerin samples from biodiesel production. Density ranged from 1.01 to $1.20 \mathrm{~g} / \mathrm{cm}^{3}$ and was lower than the density of pure glycerin $\left(1.31 \mathrm{~g} / \mathrm{cm}^{3}\right)$. Sample $\mathrm{pH}$ ranged from 6.4 to 10 , the $\mathrm{pH}$ value of pure glycerin was 6.4 . However, in the study of HANSEN et al. (2009), the $\mathrm{pH}$ of 11 crude glycerin samples ranged from 2.0 to 10.8 .

\section{Methanol}

The rumen commonly produces methanol as a product of methyl ester hydrolysis from pectin driven by bacteria and protozoa. The ruminal concentration of methanol is around $28 \mu \mathrm{g} / \mathrm{mL}$ (POL \& DEMEYER 1988, VANTCHEVA et al. 1970). Methanol is not likely accumulated in ruminal fluid since it can be used by methylotropic organisms and can be converted to acetate or butyrate (NEUMANN et al. 1999). It has also been reported that methanol in excess of what can be metabolized in the rumen has severe effects in ruminants, causing inhibition of milk synthesis, anorexia, dullness, and death (CHALMERS 1986).

Methanol is metabolized to formaldehyde by the liver enzyme alcohol dehydrogenase (ADH) (BARCELOUX et al. 2002, KRAUT \& KURTZ 2008). Formaldehyde is metabolized by the enzyme 
formaldehyde dehydrogenase to formic acid. Formate is metabolized to $\mathrm{CO} 2$ and $\mathrm{H} 2 \mathrm{O}$, a process that is dependent on liver tetrahydrofolate concentration (BARCELOUX et al. 2002, KERNS et al. 2002). This pathway is easily saturable, leading to formic acid accumulation in the blood (KRAUT \& KURTZ 2008). Formic acid can cause metabolic acidosis, hyperosmolality, retinal damage with blindness, putaminal damage with neurologic dysfunction (KRAUT \& KURTZ 2008).

WINSCO et al. (2013) evaluated the effect of methanol on intake and digestion in beef cattle. Four ruminally cannulated Holstein steers, in a $4 \times 4$ Latin Square, had ad libitum access to a grain-based diet (48.9\% corn, $10 \%$ molasses, $16 \%$ cottonseed meal, $15.6 \%$ cottonseed hulls, $7.5 \%$ rice bran, $31.1 \%$ starch, and $14.7 \%$ crude protein). Treatments consisted of four levels of methanol $(0.70,140$ and $210 \mathrm{~g} / \mathrm{d})$ infused directly into the rumen. Experimental periods were 16-days long, with 10 for adaptation and 6 for sampling. Infusions of increasing levels of methanol increased the ruminal concentration from 0 to $6,563,13,356$, and $19,831 \mathrm{ppm}$. Daily DMI, and ruminal pH, total VFA concentration, and the molar proportion of acetate did not differ among treatments. A quadratic trend for a reduction in propionate proportion was observed, and was likely the result of a quadratic increase in butyrate. No adverse health or well-being effects were observed when methanol was infused.

\section{Glycerin as feed ingredient}

ZACARONI (2010) evaluated the response of lactating cows to the complete replacement of finely ground mature corn by crude glycerin in a crossover design experiment with 21 -d periods. An isonitrogenous mixture of crude glycerin plus soybean meal replaced finely ground mature corn in the diet. The crude glycerin contained $6.29 \%$ moisture, $76.2 \%$ glycerol, $1.33 \%$ ether extract, $2.93 \%$ ash, and $0.88 \%$ methanol. The dietary content of glycerin was $12.3 \%$ of DM, the content of corn was $14.8 \%$ in the Control diet. The replacement of corn with crude glycerin depressed milk yield by $10 \%$, without affecting intake, and reduced feed efficiency. Glycerin feeding reduced the daily secretion of lactose, and there was a trend for reduced milk protein secretion. Total tract apparent digestibility of organic matter (OM) was increased when glycerol replaced starch. Glycerin increased the molar proportion of butyrate and decreased the proportion of acetate in rumen fluid but had no effect on ruminal propionate. Glycerin reduced the content of glucose in the blood plasma.

SHIN et al. (2012) evaluated the replacement of ground corn, corn gluten feed, and citrus pulp with crude glycerin for dairy cows. Twenty four Holsteins, in a $2 \times 3$ factorial arrangement of treatments, were fed two roughage sources (cottonseed hulls or corn silage) and three dietary concentrations of glycerin $(0,5$, or $10 \%$ of DM). Crude glycerin contained $12 \%$ water, $5 \%$ fat, $6.8 \%$ sodium chloride, and $0.4 \%$ methanol. Crude glycerin at $5 \%$ of diet DM increased DMI without affecting milk yield. For these diets with low fiber content $(24.4 \% \mathrm{NDF})$, the content of milk fat $(3.12 \%$ for $0 \%$ glycerin) was reduced when $10 \%$ glycerin was fed (3.03\%). Total tract NDF digestibility was also $30 \%$ lower for the $10 \%$ glycerin diet compared to Control. Diets with 5 and $10 \%$ crude glycerin improved $4 \%$ fat-correct milk when corn silage was fed, but decreased it when cottonseed hulls replaced corn silage.

OMAZIC et al. (2013) evaluated the effect of low and high purity glycerin on intake, lactation performance, blood metabolites and body condition scores (BCS) for dairy cows. Forty-two cows were allocated to 14 blocks based on parity and expected day of parturition and were randomly assigned to a treatment. Treatments were: Control, and low or high purity glycerin, both at $0.5 \mathrm{~kg} / \mathrm{d}$, starting at day 2 postpartum for 28 days. The low purity glycerin contained $88.1 \%$ glycerol, $9.3 \%$ moisture, $0.9 \%$ ash, and $0.8 \%$ methanol. High purity glycerin contained $99.5 \%$ glycerol. Grass silage and concentration were fed separately four times a day. Glycerin was top dressed to the concentrate at $9 \mathrm{AM}$ and $5 \mathrm{PM}$, in equal amounts. Low and high purity glycerin had no effect on BCS and silage and total intakes. There were trends for increased yield of milk and contents of fat and protein for cows fed high compared to low purity glycerin, but milk lactose content responded in the opposite direction to the same treatments. Treatments had no effect on the content in plasma of glucose, insulin, non-esterified fatty acid (NEFA), and BHBA.

BOYD et al. (2013) evaluated the effect of replacing a portion of ground corn with crude glycerin on rumen fermentation profile, blood metabolites, and nutrient digestibility in lactating cows. Six rumen cannulated Holsteins (56 $\pm 18 \mathrm{DIM}$ ) producing $38 \pm 8.2 \mathrm{~kg}$ of milk/d were used. The design was a replicated $3 \times 3$ Latin Square with 4-week periods. Treatments were: Control, $200 \mathrm{~g}$ of glycerin/d (G2), or $400 \mathrm{~g}$ of glycerin/d (G4). Glycerin contained 80 to $85 \%$ glycerol, $14 \%$ moisture, $7 \%$ sodium chloride and $18 \mathrm{ppm}$ of methanol. There was a decrease in DMI with increasing amounts of glycerin. Milk yield was reduced by 1.8 $\mathrm{kg} / \mathrm{d}$ and $2.4 \mathrm{~kg} / \mathrm{d}$ for G4 compared with Control and G2. Treatment G2 reduced milk fat content and yield compared to Control. Blood glucose and urea- $\mathrm{N}$ did not differ among treatments. The molar proportions in rumen fluid of acetate and valerate and the acetate to propionate decreased, and the proportion of propionate and butyrate increased with increased glycerin feeding. 
Eight Jerseys received diets containing $0,4,8$, and $12 \%$ crude glycerin (WILBERT et al. 2013). The design was a replicated $4 \times 4$ Latin Square with 17 -d periods. The crude glycerin contained $81.4 \%$ glycerol, $14 \%$ moisture, $1.1 \% \mathrm{CP}$, and greater than $50 \mathrm{ppm}$ methanol. Crude glycerin had no effect on milk and energy correct milk yield, and on fat, lactose, and total milk solids content and yield. Milk protein content was increased by $12 \%$ and $8 \%$ crude glycerin in the diet. There was no treatment effect on intake, digestibility of $\mathrm{DM}, \mathrm{OM}$ and NDF, and serum concentrations of NEFA and urea-N. The response in plasma glucose to glycerol feeding was quadratic, with a reduction at the lower levels ( 4 and $8 \%$ crude glycerin) and subsequent increase ( $12 \%$ crude glycerin).

\section{In vitro studies}

Early studies on glycerol metabolism suggest that it is rapidly fermented in the rumen. GARTON et al. (1961) observed that the disappearance of glycerol after $2 \mathrm{~h}$ of incubation in rumen fluid in vitro was $25 \%$, and that $90 \%$ disappeared when incubations were performed for $8 \mathrm{~h}$. RÉMOND et al. (1993) added glycerol to continuous fermenters containing starch or cellulose. Glycerol reduced $\mathrm{pH}$ fluid more when starch was the substrate than with cellulose. The molar proportion of butyrate was increased only when glycerol was added to fermenters containing starch. The authors concluded that glycerol is rapidly fermented in the rumen and the response in ruminal propionate and butyrate to glycerol feeding is diet dependent.

Continuous fermenters were used by ABO EL-NOR et al. (2010) to investigate the effect of substituting corn with glycerol at different levels on fermentation profile and DNA concentration of selected rumen bacteria. Four dual-flow continuous culture systems were used in $4 \times 4$ Latin Square, with 10-day periods. Diets were formulated with glycerol (grade: $995 \mathrm{~mL} / \mathrm{L}$ ) at 0 (Control), 36, 72, and $108 \mathrm{~g} / \mathrm{kg}$ of DM. Substituting corn for glycerol had no effect on DM digestibility, however, feeding glycerol at 72 and $108 \mathrm{~g} / \mathrm{kg}$ of DM reduced NDF and tended to reduce ADF digestibility compared to Control. The molar proportion of acetate decreased with glycerol feeding and was the lowest with $108 \mathrm{~g} / \mathrm{kg} \mathrm{DM}$. The acetate to propionate ratio decreased with 72 and $108 \mathrm{~g} / \mathrm{kg}$ of DM and the molar proportion of butyrate and isovalerate were increased by glycerol compared to Control, but were similar among glycerol levels. Glycerol did not determine the DNA concentration for Ruminococcus albus and Succinivibrio dextinosolvens. Relative to Control, the DNA concentration for Selenomonas ruminantium and Butyrivibrio fibrisolvens were decreased on diets containing 72 and $108 \mathrm{~g} / \mathrm{kg}$ of glycerol. The DNA concentration for Clostridium proteoclasticum was decreased by glycerol feeding, but did not differ among glycerol levels. These results suggest that substituting corn with glycerol at low level has no adverse effect on fermentation, digestion, and ruminal bacteria. Higher substitution levels may have negative impact on fiber digestion and reduce acetate production.

KRUEGER et al. (2010) evaluated the effect of glycerol on ruminal fat lipolysis in vitro. Three levels were evaluated: 0,2 and $20 \%$ of glycerol in tubes containing $10 \%$ of olive oil. Both levels of glycerol inhibited lipolysis, inducing reductions by $48 \%$ and $77 \%$ in free fatty acid accumulation in rumen fluid as compared to Control. The effect of glycerol on fermentation kinetics of alfalfa hay was also evaluated. Five levels of glycerol were used: $0,5,10,20$ or $40 \%$. Gas production was measured using a computerized gas monitoring apparatus. The fast and slow degrading pools were assumed to represent glycerol and fiber, respectively. Gas accumulation of the first pool increased linearly as the amount of glycerol was increased. Higher levels of glycerol induced a quadratic decrease in first pool fractional rate of fermentation, the fractional rate of fermentation was slower at $20 \%$ and $40 \%$ compared to 0 , 5, and $10 \%$ glycerol. Glycerol reduced the fractional degradation rate of the second pool. Increasing levels of glycerol induced a linear decrease in acetate accumulation, and a quadratic increase in propionate, reducing the acetate to propionate ratio. Data suggested that long term feeding glycerol might ultimately select and enrich the populations of glycerol fermenting microbes such as Megasphaera elsdenii and Selenomonas rumiantium.

AVILA et al. (2011) evaluated the impact of increasing dietary levels $(0,7,14,21 \%$ glycerol) on the in vitro ruminal fermentation and methane production of a barley based high concentrated diet. Methane production did not differ among treatments. However, AVILA et al. (2013), using a semi continuous fermentation system to evaluate the inclusion of glycerol at $0,5,10$ and $15 \%$ DM replacing corn silage, observed a linear increase in methane in response to increased glycerol levels, resulting in a linear increase in the methane to digested DM ratio. Glycerol decreased acetate and increased butyrate and propionate production.

The effects of substituting corn with glycerol as a feed alternative were investigated using continuous fermenters by ABO EL-NOR et al. (2010). Four fermenters were used in a $4 \times 4$ Latin square design with four 10-day consecutive periods. Treatment diets contained 0 (T1), 36 (T2), 72 (T3) and 108 (T4) g glycerol/kg dry matter (DM). Diets consisted of $600 \mathrm{~g} / \mathrm{kg}$ alfalfa hay, $400 \mathrm{~g} / \mathrm{kg}$ concentrate (DM basis), and glycerol replaced the corn in the concentrate. Results showed that neutral detergent fiber digestibility decreased 
$(\mathrm{P}<0.05)$ with the T3 and T4 diets compared with the T1 diet.

Glycerol substitution had no effects on fermenters $\mathrm{pH}$, NH3-N concentration, and digestibility coefficients of DM and acid detergent fiber. The molar proportion for acetate decreased $(P<0.05)$ while the molar proportions for butyrate, valerate and isovalerate increased $(P<0.05)$ with the glycerol diets compared with the T1 diet. The DNA concentrations for Butyrivibrio fibrisolvens and Selenomonas ruminantium decreased $(P<0.05)$ with the T3 and T4 diets compared with the T1 diet. The DNA concentration for Clostridium proteoclasticum also decreased $(\mathrm{P}<0.05)$ with glycerol substitution. No differences in the DNA concentrations for Ruminococcus albus and Succinivibrio dextrinosolvens between diets were observed. Results from this study suggest that substituting corn with glycerol at low level had no adverse effects on fermentation, digestion or ruminal bacteria (ABO EL-NOR et al. 2010).

\section{Glycerol absorption}

Homologous water channel proteins (ROJEK et al. 2008) mediate glycerol transport across epithelia. Aquaporins are channels that facilitate the transport of water across the cell membrane (KING et al. 2004). These channels possess two highly conserved asparagines-proline-alanine boxes, which is essential to the formation of a water-transporting pore (MAEDA et al. 2008). Aquaporins form a simple pore that enables water to pass through the cell membrane bidirectionally according to osmosis; they are not pumps or exchangers (HUB \& GROOT 2008). Thirteen aquaporin subtypes have been identified in mammals (CAMPOS et al. 2011, MAEDA et al. 2008). It can be divided into two major groups: those selective for water and functioning as water channels (called orthodox aquaporins) and those permeable to small solutes including glycerol (called aquaglyceroporins) (CAMPOS et al. 2011).

Among them, types 3, 7, 9 and 10 are subcategorized as well as water (MAEDA et al. 2008). Two subtypes ( 7 and 9$)$ are highly expressed in adipocytes and the liver and are important parts in the homeostasis of metabolism. The expression and physiological function of aquaporins are less investigated in ruminants (RØJEN et al. 2011). Glycerol channels were presumed to prevent acute rises in intracellular osmotic pressure while glycerol production was increased during lipolysis in adipocytes. The identification of aquaglyceroporins, however, indicated a mechanism of glycerol metabolism, especially in adipocytes and hepatocytes (MAEDA et al. 2008). AQP3 expression has been reported in several mammalian tissues including kidney, epidermis, urinary, respiratory and digestive tracts (TAKATA et al. 2004), and human erythrocyte (ROUDIER et al. 1998). AQP3 is moderately permeable to water, but highly permeable to glycerol and possibly to urea (CAMPOS et al. 2011).

RØJEN et al. (2011) observed the AQP3 expression in ruminal papillae and mRNA expression and protein abundance are affected by diet. AQP7 is highly expressed in white and brown adipose tissues from rats and humans, and a weak expression is also observed in cardiac and skeletal muscle and the kidney (MAEDA et al. 2008).

\section{CONCLUSION}

In several studies it is possible to observe that the crude glycerin can be included in the diet of ruminant animals causing no negative effects on dairy cow performance, digestion, metabolism and blood acid-base balance. It is necessary to know the glycerin composition for the correct application. Studies on the deleterious effects of the inclusion of crude glycerin with high methanol content in the ruminant animal diet should be performed.

\section{REFERENCES}

ABO EL-NOR SAH et al. 2010. Effects of differing levels of glycerol on rumen fermentation and bactéria. Fuel and Energy Abstracts 162: 99-105.

ANVISA. 1999. Agência Nacional de Vigilância Sanitária. Resolução no 386, de 5 de agosto de 1999. Regulamento técnico sobre aditivos utilizados segundo as boas práticas de fabricação e suas funções. Available in: <http://portal.anvisa.gov.br/wps/wcm/connect/0556e3004745787485bdd53fbc4c6735/RESOLUCAO_386_1999.pdf?M OD=AJPERES $>$. Accessed in: April 22, 2014.

ANAND P \& SAXENA RK. 2011. A comparative study of solvent-assisted pretreatment of biodiesel derived crude glycerol on growth and 1,3-propanediol production from Citrobacter freundii. New Biotechnology 29: $199-205$.

AVILA JS et al. 2011. Effects of replacing barley grain in feedlot diets with increasing levels of glycerol on in vitro fermentation and methane production. Animal Feed Science Technology 166/167: 265-268.

AVILA JS et al. 2013. Effects of increasing concentrations of glycerol in concentrate diets on nutrient digestibility, methane emissions, growth, fatty acid profiles, and carcass traits of lambs. Journal of Animal Science 91: 829-837.

BARCELOUX DG et al. 2002. American Academy of Clinical Toxicology practice guidelines on the treatment of methanol poisoning. Journal of Clinical Toxicology 40: 415-446.

BIOFUEL DIGEST. 2013. Glycerine seen as potential renewable marine fuel. Washington, DC. Available in:

Rev. Ciênc. Agrovet., Lages, SC, Brasil (ISSN 2238-1171) 409 
https://www.biofuelsdigest.com/bdigest/tag/glycerin/. Accessed in: December 20, 2018.

BOYD $\mathrm{J}$ et al. 2011. Effects of the addition of direct-fed microbials and glycerol to the diet of lactating dairy cows on milk yield and apparent efficiency of yield. Journal of Dairy Science 94: 4616-4622.

BOYD $J$ et al. 2013. Effects of feeding different amounts of supplemental glycerol on ruminal environment and digestibility of lactating dairy cows. Journal of Dairy Science 96: 470-476.

CAMPOS E et al. 2011. Lack of Aquaporin 3 in bovine erythrocyte membranes correlates with low glycerol permeation. Biochemical and Biophysical Research Communications 408: 477-481.

CARVALHO ER et al. 2011. Replacing corn with glycerol in diets for transition dairy cows. Journal of Dairy Science 94 : 908-916.

CELIK E et al. 2008. Use of biodiesel byproduct crude glycerol as the carbon source for fermentation processes by recombinant Pichia pastoris. Industrial \& Engineering Chemistry Research 47: 2985-2990.

DASARI MA et al. 2005. Low-pressure hydrogenolysis of glycerol to propylene glycol. Applied Catalysis A: General 281: 225-231.

DONKIN SS et al. 2009. Feeding value of glycerol as a replacement for corn grain in rations fed to lactating dairy cow. Journal of Dairy Science 92: 5111-5119.

ELLIOT JM. 1976. The glucose economy of the lactating dairy cow. In: Proceedings... Cornell Nutrition Conference for Feed Manufacturers. New York: Cornell University. p. 59-66

FDA. 2006. Food and Drug Administration. Code of Federal Regulations, Title 21. Vol. 6. 21CFR582.1320.

GARTON GA et al. 1961. Glyceride hidrolysis and glycerol fermentation by sheep rumen contents. Journal of General Microbiology 25: 215-225.

HANSEN CF et al. 2009. A chemical analysis of samples of crude glycerol from the production of biodiesel in Australia, and the effects of feeding crude glycerol to growing-finishing pigs on performance, plasma metabolites and meat quality at slaughter. Animal Production Science 49: 154-161.

HARZIA $\mathrm{H}$ et al. 2013. Crude glycerol as glycogenic precursor in feed; effects on milk coagulation properties and metabolic profiles of dairy cows. Journal of Dairy Research 80: 190-196.

HIPPEN AR et al. 2008. Glycerol and other energy sources for metabolism and production of transition dairy cows. In: Proc. Annual Florida Ruminat Nutrition Symposium. Proceedings... Gainesville: University of Florida. p.123.

HUB JS \& GROOT BL. 2008. Mechanism of selectivity in aquaporins and aquaglyceroporins. Proceedings of the National Academy of Sciences 105: 1198-1203.

HU S et al. 2012. Characterization of crude glycerol from biodiesel plants. Journal of Agricultural and Food Chemistry 60: 5915-5921.

JOHNSON DT \& TACONI KA. 2007. The glycerin glut: options for the value added conversion of crude glycerol resulting from biodiesel production. Environmental Progress 26: 338-348.

KERNS W et al. 2002. Formate kinetics in methanol poisoning. Journal of Toxicology 40: 137-143.

KING LS et al. 2004. From structure to disease: the envolving tale of aquaporin biology. Nature Reviews. Molecular Cell Biology 5: 687-698.

KRAUT JA \& KURTZ I. 2008. Toxic alcohol ingestions: clinical features, diagnosis, and management. Clinical Journal of the American Society of Nephrology 3: 208-225.

KRUEGER NA et al. 2010. Evaluation of feeding glycerol on free-fatty acid production and fermentation kinetics of mixed ruminal microbes in vitro. Bioresource Technology 101: 8469-8472.

LENG RA. 1970. Formation and production of volatile fatty acids in the rumen. In: PHILLIPSON AT. (Ed.). Physiology of Digestion and Metabolism in the Ruminant. Newcastle-upon-Tyne: Oriel. p.406-421.

LIN ECC. 1977. Glycerol utilization and its regulation in mammals. Annual Review of Biochemistry 46: 765-795.

LINKE PL et al. 2004. Ruminal and plasma responses in dairy cows to drenching or feeding glycerol. Journal of Dairy Science 87: 343.

MAEDA N et al. 2008. Metabolic impact of adipose and hepatic glycerol channels aquaporin 7 and aquaporin 9. Nature Clinical Pratice: Endocrinology \& Metabolism 4: 627-634.

MCCOY M. 2006. Glycerin surplus: plants are closing, and new uses for the chemical are being found. Chemical \& Engineering News 84:7.

NRC. 2001. National Research Council. Nutrient requirements of dairy cattle. 7.ed. Washington: National Academy. $381 \mathrm{p}$.

NEUMANN L et al. 1999. Effect of methanol on methanogenesis and fermentation in the rumen simulation technique (RUSITEC). Journal of Animal Physiology and Animal Nutrition 82: 142-149.

OMAZIC AW et al. 2013. High- and low-purity glycerine supplementation to dairy cows in early lactation: effects on silage intake, milk production and metabolism. Animal 7: 1479-1485.

POL A \& DEMEYER DI. 1988. Fermentation of methanol in the sheep rumen. Applied and Environmental Microbiology 54: 832-834.

PYLE DJ et al. 2008. Producing docosahexaenoic acid (DHA) - rich algae from biodiesel-derived crude glycerol: effects of impurities on DHA production and algal biomass composition. Journal of Agricultural and Food Chemistry 56: 39333939.

RÉMOND B et al. 1993. In vitro and in vivo fermentation of glycerol by rumen microbes. Animal Feed Science and Technology 41: 121-132.

ROJEK A et al. 2008. A current view of the mammalian aquaglyceroporins. Annual Review of Physiology 70: $301-327$.

Rev. Ciênc. Agrovet., Lages, SC, Brasil (ISSN 2238-1171) 410 
RØJEN BA et al. 2011. Short communication: effects of dietary nitrogen concentration on messenger RNA expression and protein abundance of urea transporter-B and aquaporins in ruminal papillae from lactating Holstein cows. Journal of Dairy Science 94: 2587-2591.

ROUSSEAUX CR et al. 1982. Methyl Alcohol Toxicity in Cattle. Canadian Veterinary Journal 23: 252.

ROUDIER $\mathrm{N}$ et al. 1998. Evidence for the presence of aquaporin-3 in human red blood cells. The Journal of Biological Chemistry 273: 8407-8412.

SANTIBANEZ C et al. 2011. Residual glycerol from biodiesel manufacturing, waste or potential source of bionergy: a review. Chilean Journal of Agricultural Research 71: 469-475.

SCHRÖDER A \& SÜDEKUM KH. 1999. Glycerol as a by-product of biodiesel production in diets for ruminants. In: New horizons for an old crop. Proceedings... Canberra: International Rapeseed. 241p.

SHIN JH et al. 2012. Effects of feeding crude glycerin on performance and ruminal kinetics of lactating Holstein cows fed corn silage- or cottonseed hull-based, low-fiber diets. Journal of Dairy Science 95: 4006-4016.

TAKATA $\mathrm{K}$ et al. 2004. Aquaporins: water chanel proteins of cell membrane. Progress in Histochemistry and Cytochemistry 39: 1-83.

VANTCHEVA ZM et al. 1970. Rumen methanol in vivo and in vitro. Journal of Dairy Science 53: 1511-1514.

WILBERT CA et al. 2013. Crude glycerin as an alternative energy feedstuff for dairy cows. Animal Feed Science and Technology 183: 116-123.

WINSCO KN et al. 2013. Effect of methanol on intake and digestion in beef cattle. Texas Cattle Feeders Associaton. 7p. ZACARONI OF. 2010. Resposta de vacas leiteiras à substituição de milho por glicerina bruta. Dissertação (Mestrado em Zootecnia). Lavras: UFLA. 43p. 